\title{
ANALISIS FAKTOR-FAKTOR YANG MEMPENGARUHI KEIKUTSERTAAN SENAM HAMIL PADA IBU HAMIL DI BPS NINA SURABAYA
}

\author{
Uliyatul Laili \\ Fakultas Keperawatan dan Kebidanan \\ Universitas Nahdlatul Ulama Surabaya J1. Smea 57 Surabaya \\ E-mail: uliyatul.laili@unusa.ac.id
}

\begin{abstract}
Analysis of factors Affecting The Participant Pregnant Women Gymnactics in BPS Nina Surabaya. Pregnant women should get treatment during pregnancy. Treatment during pregnancy or antenatal care can be done via examination of pregnancy, pregnancy exercise, nutrition and other compliance requirements. Pregnancy exercise is an exercise undertaken to prepare and train the muscles so that it can be used to function optimally in a normal delivery.This study uses an analytical method with cross sectional design prospective. Sampling using total sampling technique. The independent variable is education, parity and maternal knowledge, while the dependent variable is exclusive breastfeeding. Data were analyzed using chi square test.The results showed a correlation between age and support of husband / family with the participation of pregnant women during pregnancy exercise with a p-value of $<0.05$, whereas for education and parity are not related to the participation of pregnant women against pregnancy exercise with a value of $p>0.05$. The conclusions of this study are the factors that influence the participation of pregnant women during pregnancy exercise is aged and the support of husband / family.
\end{abstract}

\begin{abstract}
Abstrak : Analisis Faktor-Faktor yang Mempengaruhi Keikutsertaan Senam hamil pada Ibu Hamil di BPS Nina Surabaya. Ibu hamil perlu mendapatkan perawatan selama kehamilan. Perawatan selama kehamilan atau antenatal care dapat dilakukan melalui pemeriksaan kehamilan, senam hamil, pemenuhan kebutuhan nutrisi dan lainnya. Senam hamil merupakan senam yang dilakukan untuk mempersiapkan dan melatih otot-otot sehingga dapat dimanfaatkan untuk berfungsi secara optimal dalam persalinan normal. Penelitian ini menggunakan metode analitik dengan rancang bangun cross sectional prospective. Pengambilan sampel menggunakan teknik total sampling. Variabel independent adalah pendidikan, paritas dan pengetahuan ibu, sedangkan variabel dependent adalah pemberian ASI eksklusif. Data dianalisis dengan menggunakan uji chi square. Hasil penelitian menunjukkan terdapat hubungan antara umur dan dukungan suami/ keluarga dengan keikutsertaan ibu hamil pada senam hamil dengan nilai $\mathrm{p}<0.05$, sedangkan untuk pendidikan dan paritas tidak berhubungan dengan keikutsertaan ibu hamil terhadap senam hamil dengan nilai $\mathrm{p}>0.05$. Simpulan dari penelitian ini adalah faktor yang mempengaruhi keikutsertaan ibu hamil pada senam hamil adalah umur dan dukungan suami/ keluarga.
\end{abstract}

Kata kunci : karakteristik ibu hamil, dukungan suami/ keluarga dan senam hamil 


\section{PENDAHULUAN}

Kehamilan merupakan proses alamiah (normal) dan bukan proses patologis, tetapi kondisi normal dapat menjadi patologi. Menyadari hal tersebut dalam melakukan asuhan tidak perlu melakukan intervensiintervensi yang tidak perlu kecuali ada indikasi (Sulistyawati, 2009). Ibu hamil perlu mendapatkan perawatan selama kehamilan. Perawatan selama kehamilan atau antenatal care dapat dilakukan melalui pemeriksaan kehamilan, senam hamil, pemenuhan kebutuhan nutrisi dan lainnya.

Senam hamil merupakan senam yang dilakukan untuk mempersiapkan dan melatih otot-otot sehingga dapat dimanfaatkan untuk berfungsi secara optimal dalam persalinan normal (Manuaba, 2010). Tujuan dilaksanakan senam hamil diantaranya yaitu melalui latihan yang teratur dapat dijaga kondisi otot - otot dan persendian yang berperan dalam proses mekanisme persalinan, memperkuat dan mempertahankan elastisitas otot - otot dinding perut, otot - otot dasar panggul, ligament, dan jaringan yang berperan dalam mekanisme persalinan, melenturkan persendian- persendian yang berhubungan dengan proses persalinan, membentuk sikap tubuh yang prima, sehingga dapat membantu mengatasi keluhan-keluhan, letak janin, dan mengurangi sesak nafas, mengenai teknik teknik pernafasan dalam persalinan dan dapat mengatur diri pada ketenangan.

Berdasarkan penelitian yang dilakukan oleh inka dan arif menunjukkan bahwa terdapat hubungan yang kuat antara keikutsertaan senam hamil dengan kecemasan pada ibu primigravida.(inka, 2010). Keikutsertaan dalam senam hamil dipengaruhi oleh beberapa faktor diantaranya adalah pengetahuan ibu tentang senam hamil, latar belakang pendidikan, motivasi, dukungan suami dan keluarga, pekerjaan dan lain sebagainya.

Penelitian yang dilakukan di Semarang menunjukkan bahwa terdapat hubungan antara keikutsertaan senam hamil adalah umur ibu $(\mathrm{p}=0,008)$, pendidikan ibu $(\mathrm{p}=0,028)$, pengetahuan ibu $(\mathrm{p}=0,014)$, ketersediaan program senam hamil $(\mathrm{p}=0,034), \quad$ dukungan suami/keluarga $(\mathrm{p}=0,004)$.

Oleh karena itu, peneliti ingin mengetahui faktor-faktor yang dapat mempengaruhi keikutsertaan senam hamil.

\section{METODE}

Desain penelitian yang digunakan adalah analitik dengan pendekatan yang digunakan adalah cross sectional prospective yaitu suatu penelitian dimana variabel independen (umur, pendidikan, paritas, dukungan suami/ keluarga) dan dependen (keikutsertaan senam hamil) diobservasi pada waktu yang sama. Populasi dalam penelitian ini adalah adalah semua ibu hamil yang usia kehamilannya lebih dari 28 minggu di BPS Nina Surabaya, sebanyak 28 orang, kemudian di ambil sampel secara keseluruhan. Disebut dengan total sampling. Data dianalisis dengan menggunakan uji statistic chi square dengan menggunakan SPSS dengan tingkat signifikansi 0,05.

\section{HASIL PENELITIAN}

Karakteristik responden berdasarkan Tabel 1 Distribusi frekuensi responden

\begin{tabular}{|c|c|c|}
\hline Variabel & $\mathrm{n}$ & $(\%)$ \\
\hline \multicolumn{3}{|l|}{ Umur } \\
\hline Kehamilan resiko tinggi & 10 & 36 \\
\hline $\begin{array}{l}\text { Kehamilan resiko } \\
\text { rendah }\end{array}$ & 18 & 74 \\
\hline \multicolumn{3}{|l|}{ Pendidikan } \\
\hline SMA/ sederajat & 21 & 75 \\
\hline Pendidikan Tinggi & 7 & 25 \\
\hline
\end{tabular}

Paritas 


\begin{tabular}{lll}
\hline \multicolumn{1}{c}{ Nullipara } & 11 & 39 \\
Primipara & 17 & 71 \\
\hline Dukungan & & \\
suami/keluarga & & \\
Ya & 21 & 75 \\
Tidak & 7 & 25 \\
\hline
\end{tabular}

Pada tabel 1 menunjukkan bahwa dari 28 responden, sebagian besar responden berdasarkan umurnya termasuk kehamilan resiko rendah (74\%), pendidikan SMA/ sederajat $(75 \%)$, primipara $(71 \%)$ dan mendapatkan dukungan suami/ keluarga $(75 \%)$.

Tabel 2 Distribusi frekuensi keikutsertaan senam hamil

\begin{tabular}{cll}
\hline Senam hamil & $\mathbf{n}$ & $\mathbf{( \% )}$ \\
\hline Ya & 17 & 61 \\
\hline Tidak & 11 & 39 \\
\hline Jumlah & 28 & 100 \\
\hline
\end{tabular}

Pada table 2 menunjukkan bahwa dari 28 responden sebagian besar responden $(61 \%)$ mengikuti senam hamil.

Tabel 3 Hubungan antara senam hamil dengan umur, pendidikan, paritas dan dukungan suami/ keluarga

\begin{tabular}{|c|c|c|c|c|c|}
\hline \multirow{3}{*}{ Variabel } & \multicolumn{4}{|c|}{ Senam hamil } & \multirow{3}{*}{$\begin{array}{c}\mathrm{p} \\
\text { value }\end{array}$} \\
\hline & \multicolumn{2}{|c|}{$\mathrm{Ya}$} & \multicolumn{2}{|c|}{ Tidak } & \\
\hline & $\mathbf{n}$ & $\%$ & $\mathrm{n}$ & $\%$ & \\
\hline \multicolumn{6}{|l|}{ Umur } \\
\hline Kehamilan & 2 & 7 & 3 & 11 & \multirow{3}{*}{0.001} \\
\hline resiko tinggi & & & & & \\
\hline $\begin{array}{l}\text { Kehamilan } \\
\text { resiko rendah }\end{array}$ & 15 & 54 & 8 & 28 & \\
\hline \multicolumn{6}{|l|}{ Pendidikan } \\
\hline SMA/ & 12 & 43 & 9 & 32 & \multirow{3}{*}{0.503} \\
\hline sederajat & & & & & \\
\hline PT & 5 & 17 & 2 & 8 & \\
\hline \multicolumn{6}{|l|}{ Paritas } \\
\hline Nullipara & 8 & 28 & 3 & 12 & \multirow[t]{2}{*}{0.295} \\
\hline Primipara & 9 & 32 & 8 & 28 & \\
\hline $\begin{array}{l}\text { Dukungan } \\
\text { suami/keluarga }\end{array}$ & & & & & 0.004 \\
\hline
\end{tabular}

\begin{tabular}{lllll}
\hline Ya & 16 & 57 & 5 & 18 \\
Tidak & 1 & 4 & 6 & 21
\end{tabular}

Berdasarkan tabel di atas menunjukkan bahwa umur dan dukungan suami/ keluarga berhubungan dengan keikutsertaan senam hamil dengan nilai $\mathrm{p}<0,05$.

\section{PEMBAHASAN}

Analisis faktor-faktor yang mempengaruhi keikutsertaan senam hamil.

Dari hasil tabel diatas kemudian dilakukan analisis dengan uji chi square menunjukkan bahwa umur dan dukungan suami/ keluarga memiliki nilai $\mathrm{p}<(0,05)$, sedangkan untuk pendidikan dan paritas tidak berhubungan dengan keikutsertaan terhadap senam hamil.

Penelitian lain, yang dilakukan di Semarang menunjukkan bahwa terdapat hubungan antara keikutsertaan senam hamil adalah umur ibu $(\mathrm{p}=0,008)$, pendidikan ibu $(p=0,028)$, pengetahuan ibu $(p=0,014)$, ketersediaan program senam hamil $(\mathrm{p}=0,034), \quad$ dukungan $\quad$ suami/keluarga $(\mathrm{p}=0,004)$.

Pada penelitian ini, paritas dan pendidikan tidak berhubungan dengan keikutsertaan ibu hamil terhadap senam hamil.

Sebagian besar ibu hamil yang melakukan pemeriksaan kehamilan di BPS Nina menikuti kegiatan senam hamil. Akan tetapi ada juga beberapa ibu yang tidak ikut serta. Hal ini dipengaruhi oleh banyak hal, diantaranya pada ibu multipara yang merasa sudah cukup sibuk dengan kegiatannya sehingga tidak ada waktu untuk ikut serta dalam senam hamil. Selain itu, faktor yang menyebabkan ibu tidak ikut serta dalam senam hamil adalah karena adanya pengaruh dari lingkungan sekitar karena kondisi masyarakat sebagian besar masih berpendidikan rendah. 


\section{SIMPULAN}

Terdapat hubungan antara umur dan dukungan suami/ keluarga terhadap keikutsertaan senam hamil.

Tidak terdapat hubungan antara pendidikan dan paritas terhadap keikutsertaan senam hamil.

\section{SARAN}

1. Tenaga pendidik diharapkan dapat meningkatkan kemampuan komunikasi pada peserta didik sehingga nantinya dapat memberikan konseling dengan baik.

2. diharapkan setiap bidan memiliki kompetensi dalam memberikan asuhan senam hamil.

\section{DAFTAR PUSTAKA}

A.Wawan dan Dewi M. 2010. Teori \& Pengukuiran Pengetahuan, Sikap, dan Perilaku Manusia. Nuha Medika. Yogyakarta

Arief, Khusartati, 2009. Kesehatan Reproduksi. Jakarta; Depdiknas

Bandiyah, Siti , 2009. Kehamilan ,persalinan, dan gangguan kehamilan. Nuha Medika. Yogyakarta .

Hanton, Thomas W., 2001. Panduan Senam Kebugaran Untuk Wanita Hamil. Jakarta; Raja Grafindo Persada Indriatai, MT. (2008). Senam Hamil dan Balita. Cemerlang Publishing. Yogyakarta

Kushartanti, 2004. Senam Hamil Menyamankan Kehamilan Mempermudah Persalinan. Yogyakarta: Lintang Pustaka

Mandriati, G.A. (2008). Panduan Belajar Asuhan Kebidanan Ibu Hamil. EGC. Jakarta.

Nirwana, Ade Benih. 2011. Kapita Selekta Kehamilan. Nuha Medika. Yogyakarta
Notoatmodjo, S. 2010. Metodologi Penelitian Kesehatan. Rineka Cipta. Jakarta

Nursalam, dan Siti Pariani. 2010. Pendekatan Praktis Metodologi Riset Keperawatan. CV. Agung Seto. Jakarta

Nursalam, 2003. Konsep \& Penerapan Metodologi Penelitian Ilmu Keperawatan. Jakarta; Salemba Medika

Nursalam. 2011. Konsep dan Penerapan Metodologi Penelitian Ilmu Keperawatan, Edisi II. Salemba Medika. Jakarta

Pudiastuti, R. A, 2011. Buku Ajar ; Kebidanan Komunitas. Haikhi. Yogyakarta.

Prawirohardjo, Sarwono, 2005. Ilmu Kebidanan. Jakarta; Yayasan Bina Pustaka Sarwono Prawirohardjo

Sulistiyawati, Ari . 2009. Asuhan kebidanan pada masa kehamilan. Salemba Medika. Jakarta

Wahyuni \& Nida. Q, 2010. Pengaruh Senam Hamil Terhadap Perubahan Kadar Hemoglobin ( $\mathrm{Hb}$ ) Pada Kehamilan Trimester Ketiga. Ju-rnal Kesehatan, 3(2)

Wiyono, Adi, 2004. Senam Hamil Untuk Kesehatan. Jakarta; AgroMedia Pustaka

Wulandari P. Y. 2006. Efektivitas Senam Hamil Seba-gai Pelayanan Prenatal Dalam Menurunkan Kecemasan Menghadapi Persalinan Pertama. INSAV, 8(2): 144 